doi:10.18575/msrs.sm.e.17.10 UDC 616.12-008.331.1:616.24 COBISS.RS-ID 6399768

\section{Diagnosis and Treatment of Pulmonary Hypertension}

\begin{abstract}
Pulmonary hypertension $(\mathrm{PH})$ is a hemodynamic and clinical state defined as an increase in mean pulmonary arterial pressure $\geq 25 \mathrm{mmHg}$ at rest. Five groups of patients have been defined: group 1 as pulmonary arterial hypertension (PAH), group 2 as $\mathrm{PH}$ due to left heart disease, group 3 as $\mathrm{PH}$ due to lung diseases, group 4 as chronic thromboembolic $\mathrm{PH}$, and group 5 as $\mathrm{PH}$ of other causes. $\mathrm{PAH}$ is a rapidly progressive and fatal disease with an incidence of 3 cases per million whereas incidence of $\mathrm{PH}$ due to left ventricular dysfunction is as high as $60-70 \%$ of all cases. Pulmonary capillary wedge pressure, invasively measured at rest, has been used to distinguish between pre- $(\leq 15 \mathrm{mmHg})$ and post-capillary $(>15 \mathrm{mmHg}) \mathrm{PH}$. The early clinical symptoms and signs are subtle and non-specific, such as exertional dyspnea, fatigue, pre-syncope and progressive limitation of exercise capacity so the vast majority of patients have an advanced disease with World Health Organization functional class of III or IV at first presentation. The diagnostic approach in $\mathrm{PH}$ has the goal to evaluate the two main anatomic components: pulmonary vasculature and right ventricle in order to establish the diagnosis and identify the group of $\mathrm{PH}$. The therapy for PAH patients includes three main components: general measures and supportive therapy; initial therapy with calcium channel blockers in vasoreactive or specific drugs approved for PAH in non-vasoreactive patients either single or in combination, and lung transplantation. All patients with $\mathrm{PAH}$ should be referred to $\mathrm{PH}$ expert centers for comprehensive diagnostic and therapeutic assessment.
\end{abstract}

Keywords: Pulmonary hypertension,ventricle, pulmonary arterial pressure

(Scr Med 2017:48:68-76)

\section{Tamara Kovačević Preradović ${ }^{1}$, Bojan Stanetić ${ }^{\prime}$}

${ }^{1}$ Department of Cardiology, University Clinical Centre of the Republic of Srpska, Banja Luka; Faculty of Medicine, Univeristy of Banja Luka, Republic of Srpska

\section{Contact address:}

Tamara Kovačević-Preradović, Department of Cardiology, University Clinical Centre of the Republic of Srpska,

Street address: 12 beba $b b$

78 ooo Banjaluka

Republic of Srpska

Bosnia i Herzegovina

e-mail:tamara.kovacevic@

medicolaser.info

phone number: +387-66-941-391

Submitted: February $10^{\text {th }}, 2017$ Accepted: February 28 ${ }^{\text {th }}, 2017$

\section{Definition}

Pulmonary hypertension $(\mathrm{PH})$ is an increase of the mean pressure in the pulmonary artery (mPAP) and its value ranges from $25 \mathrm{mmHg}$ upwards. Depending on the hemodynamics, it is crucial to differentiate between "precapillary" and "post-capillary" PH.

Pre-capillary PH implies mPAP $\geq 25 \mathrm{mmHg}$ and pulmonary capillary pressure (PCWP) $\leq 15 \mathrm{mmHg}$, which is why this type of hypertension is referred to as pulmonary arterial hypertension (PAH). On the other hand, post-capillary $\mathrm{PH}$ is defined as an increase of
mPAP $\geq 25 \mathrm{mmHg}$, whereas PCWP $>15 \mathrm{mmHg}$ and it is commonly the $\mathrm{PH}$ resulting from the left heart weakness. ${ }^{1}$

The increase of pulmonary vascular resistance (PVR) is the basis of vascular pathophysiology in $\mathrm{PH}$ and it results in the escalation of pressure in pulmonary artery, which further causes pressure-load in the right ventricle (RV). Compensatory mechanisms induce the right ventricular dilatation so the basic determinants of symptomatology and patient prognosis are actually the pulmonary arterial pressure values and RV function. 


\section{Classification of pulmonary hypertension}

Over the last decade, there have been a few changes in $\mathrm{PH}$ classification, especially when it comes to specific groups of patients. The most recent classification was adopted at the 2013 World Symposium on Pulmonary Hypertension held in Nice, according to which PH is divided into five groups with clearly defined sub-categories (Table 1$).{ }^{1}$

Table 1. Clinical classification of pulmonary hypertension.

1. Pulmonary arterial hypertension

1.1 Idiopatic

1.2 Heritable

1.3 Drugs and toxins induced

1.4 Associated with:

1.4.1 Connective tissue disease

1.4.2 Human immunodeficiency (HIV) infection

1.4.3 Portal hypertension

1.4.4 Congenital heart disease

1.4.5 Schistosomiasis

$1^{\star}$. Pulmonary veno-occlusive disease and/or pulmonary capillary haemangiomatosis

$1^{\star \star}$. Persistent pulmonary hypertension of the newborn

2. Pulmonary hypertension due to left heart disease

2.1 Left ventricular systolic dysfunction

2.2 Left ventricular diastolic dysfunction

2.3 Valvular disease

2.4 Congenital/acquired left heart inflow/outflow tract obstruction and congenital cardiomyopathies

2.5 Congenital/acquired pulmonary veins stenosis

3. Pulmonary hypertension due to lung disease and/or hypoxia

3.1 Chronic obstructive pulmonary disease

3.2 Interstitial lung disease

3.3 Other pulmonary disease with mixed restrictive and obstructive pattern

3.4 Sleep-disordered breathing

3.5 Alveolar hypoventilation disorders

3.6 Chronic exposure to high altitude
3.7 Developmental lung diseases

4. Chronic thromboembolic pulmonary hypertension and other pulmonary artery obstructions

4.1 Chronic thromboembolic pulmonary hypertension

4.2 Other pulmonary artery obstructions

4.2.1 Angiosarcoma

4.2.2 Other intravascular tumors

4.2.3 Arteritis

4.2.4 Congenital pulmonary arteries stenoses

4.2.5 Parasites (hydatidosis)

5. Pulmonary hypertension with unclear and/or multifactorial mechanisms

5.1 Haematological disorders: chronic haemolytic anaemia, myeloproliferative disorders, splenectomy

5.2 Systemic disorders: sarcoidosis, pulmonary histiocytosis, lymphangioleiomyomatosis, neurofibromatosis

5.3 Metabolic disorders: glycogen storage disease, Gaucher disease, thyroid disorders

5.4 Others: pulmonary tumoral thrombothic microangiopathy, fibrosing mediastinitis, chronic renal failure (with/without dialysis), segmental pulmonary hypertension

\section{Clinical features}

Symptoms and signs of $\mathrm{PH}$ are usually nonspecific which frequently results in delayed diagnosis and adequate therapy application. A most common first symptom is the shortness of breath (dyspnea) during physical activity accompanied by general ailment and disability. Other symptoms which may appear later are as follows: vertigo, disturbance of consciousness, chest pain and pressure, leg swelling (a sign of right ventricular failure). Depending on to which extent the symptoms prevent patients from physical activities, we distinguish between four functional classes of patients (WHO FC) (Table 2). The functional class of patients suffering from $\mathrm{PH}$ is directly proportional to the survival rate so that patients from WHO FC IV have the rate of survival $<40 \%$ on the three-year level. ${ }^{2}$ 
Table 2. World Health Organization (WHO) functional class of patients with PAH.

\begin{tabular}{ll} 
Functional & \\
Class & \multicolumn{1}{c}{ Symptoms } \\
& $\begin{array}{l}\text { Patients with pulmonary hypertension } \\
\text { but without resulting limitation of physical } \\
\text { activity. Ordinary physical activity does not } \\
\text { cause dyspnoea or fatigue, chest pain, or } \\
\text { near syncope. }\end{array}$ \\
& Patients with pulmonary hypertension \\
& resulting in slight limitation of physical \\
& activity. They are comfortable at rest. \\
& Ordinary physical activity causes undue \\
& dyspnoea or fatigue, chest pain, or near \\
& syncope. \\
& Patients with pulmonary hypertension \\
III & resulting in marked limitation of physical \\
& activity. They are comfortable at rest. \\
& Less than ordinary activity causes undue \\
& dyspnoea or fatigue, chest pain, or near \\
& syncope. \\
& Patients with pulmonary hypertension \\
with inability to carry out any physical \\
activity without symptoms. These patients \\
manifest signs of right heart failure. \\
Dyspnoea and/or fatigue may even be \\
present at rest. Discomfort is increased by \\
any physical activity.
\end{tabular}

\section{Diagnosis}

The PAH diagnosis begins with anamnesis, i.e. the estimation of symptoms which might indicate PH. Graph 1 displays an algorithm of procedures once we suspect of PAH. Electrocardiographic changes with patients suffering from PAH are nonspecific and they indicate the right ventricle ballast: right axis deviation, ST segment depression and/or negative $\mathrm{T}$ waves in right precordial leads $\left(V_{1}-V_{3}\right)$, right bundle branch block. The patients showing signs of right ventricular failure suffer from the common malignant disorder of heart rhythm, which is why it is crucial to periodically perform the 24-hour ECG monitoring.

At the moment of $\mathrm{PAH}$ diagnosis, more than 90\% patients have already experienced changes in heart and lung X-rays although these changes are of poor sensitivity. ${ }^{3,4}$ Typical changes are as follows: "lifting" of heart top due to right ventricular hypertrophy, right ventricular enlargement, the expansion of the main branch of pulmonary artery and/or right interlobar artery, and significant reduction of peripheral pulmonary vascular network.
Pulmonary function tests and analysis of arterial blood gas may identify the presence of respiratory diseases and pulmonary parenchyma illness. Patients suffering from PAH usually have mild to moderate lung volume reduction depending on the disease severity. The carbon monoxide diffusing capacity (DLCO) less than $45 \%$ is a bad prognosis sign and its differential diagnosis with $\mathrm{PAH}$ patients may indicate pulmonary veno-occlusive disease, PAH associated with scleroderma and parenchymal pulmonary disease. The chronic obstructive pulmonary disease which causes hypoxic $\mathrm{PH}$ is diagnosed on the basis of the irreversible airflow obstruction accompanied by an increase of residual volume, DLCO decrease, partial oxygen pressure $\left(\mathrm{PaO}_{2}\right)$, and increase of partial pressure of carbon dioxide $\left(\mathrm{PaCO}_{2}\right)$.

The transthoracic echocardiogram (TTE) is a widespread non-invasive cardiovascular diagnostic procedure pertinent for PAH patients as it helps set diagnosis and monitor the patients. TTE enables us to acquire a whole range of information as follows: evaluation of systolic, mean and diastolic pulmonary artery pressures, analysis of morphology and function of right ventricle and estimation of echocardiographic predictors of clinical outcomes in $\mathrm{PAH}$ patients.

Graph 1. Algorithm for diagnosing pulmonary arterial hypertension (PAH).

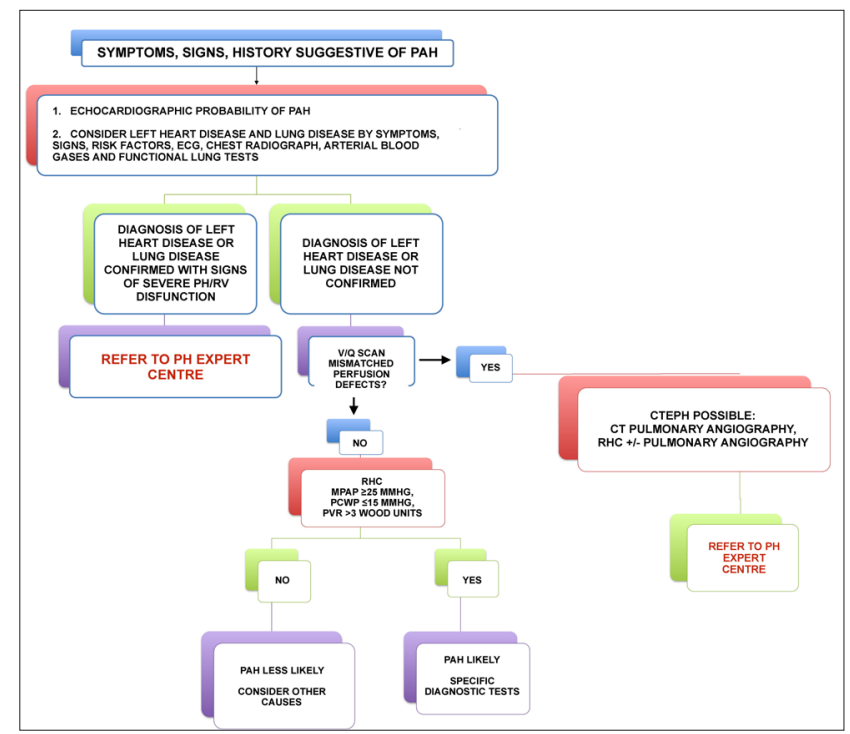

* $p$ *adapted from: Galie $N$ et al. Eur Heart $J$. 2016;37(1):67-119.(4)

$P H$, pulmonary hypertension; $R V$, right ventricle; $V / Q$ scan, a lung ventilation-perfusion scan; $R H C$, right heart catheterization; MPAP, Mean Pulmonary Arterial Pressure; PCWP, pulmonary capillary wedge pressure; PVR, pulmonary vascular resistance; CTEPH, Chronic thromboembolic pulmonary hypertension, CT, a 
computed tomography

Picture 1. Echocardiographic evaluation of pulmonary artery pressure.

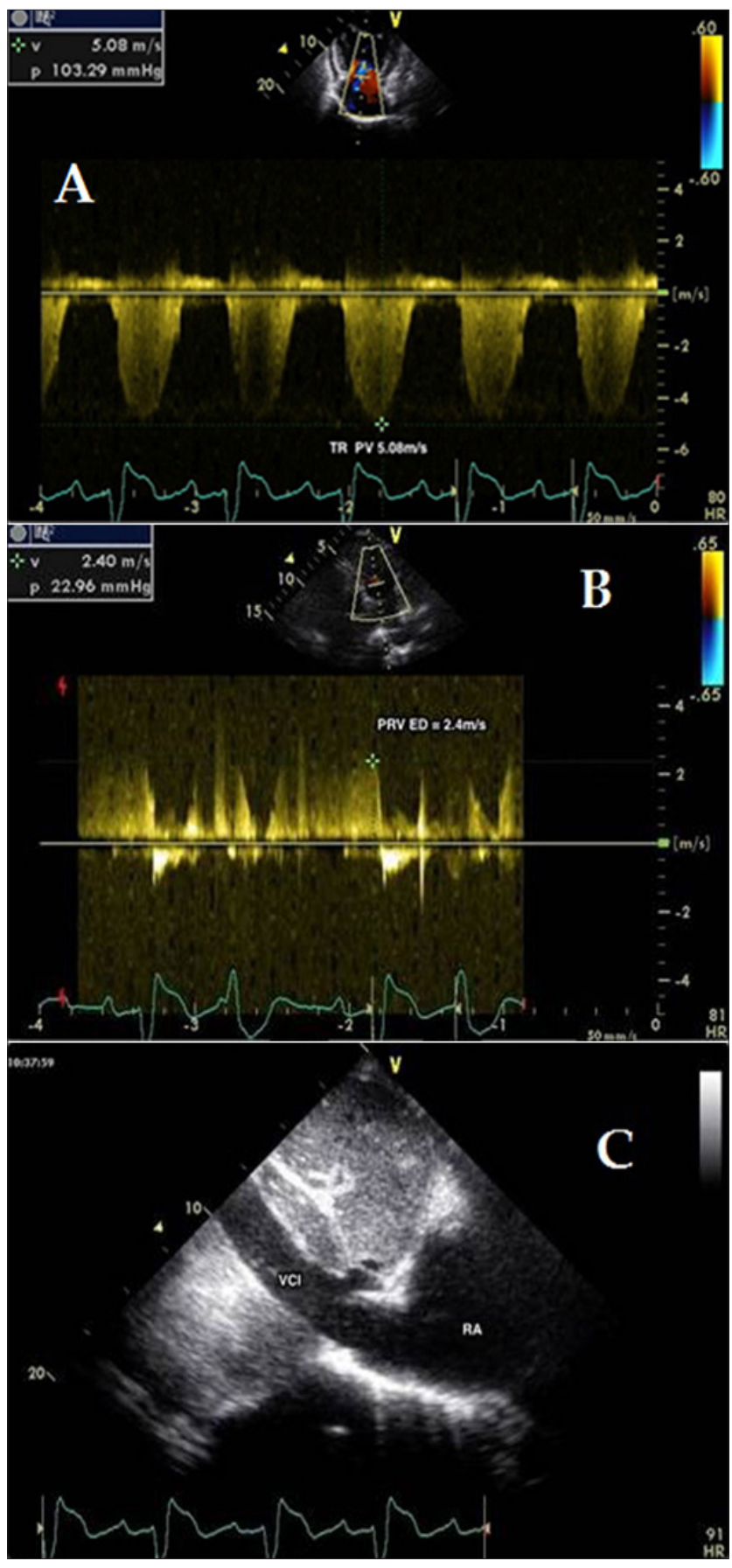

Picture 1 displays the usage of continuous-wave Doppler (CW) in order to show regurgitation of tricuspid (Picture $1, \mathrm{~A}$ ) and pulmonary (Picture 1, B) valves in PAH patients. Systolic pressure in pulmonary artery (SPAP) equals the right ventricle systolic pressure (RVSP) and it is calculated on the basis of maximum speed of tricuspid regurgitation (TRPV) and estimated right ventricle pressure (RAP) in line with the following formula: $\mathrm{RVSP}=\mathrm{SPAP}=4 \mathrm{xTRPV} 2$ + RAP. The evaluation of the right atrial pressure (RAP) is performed on the basis of diameter of vena cava inferior (VCI) and respiratory variations of its diameter: with IVC $>2.1 \mathrm{~cm}$ diameter and $<50 \%$ diameter collapse with deep inspirium, the evaluated RAP is $15 \mathrm{mmHg}$ (Picture $1, \mathrm{C}$ ). The diastolic pulmonary arterial pressure (DPAP) is calculated on the basis of the end-diastolic velocity of the pulmonary regurgitation (PRVED) in line with the following formula: DPAP $=4 \mathrm{xPRVED} 2+\mathrm{RAP}$ (Picture $1, \mathrm{~B})$. The mean pulmonary arterial pressure (MPAP) is calculated on the basis of systolic and diastolic pressures in line with the following formula: MPAP $=1 / 3 \mathrm{SPAP}+$ 2/3 DPAP. ${ }^{4-6}$

High-Resolution Computed Tomography (CT) provides us with pertinent information on potential changes in pulmonary parenchyma and enables us to eliminate emphysema, bronchitis and interstitial lung disease diagnosis, infarction, and vascular and pericardial malformations. It may also be useful to diagnose pulmonary veno-occlusive disease with typical pulmonary abnormalities such as "milk glass image", interstitial edema and bilateral interlobular septal thickening.?

Speaking of the acute pulmonary embolism diagnosis, the CT angiography has been a widely used method of choice and it has practically replaced the ventilationperfusion lung scan. On the other hand, V/Q scan is a method of choice with diagnosing the chronic thromboembolic pulmonary hypertension (CTEPH). ${ }^{8-10}$ The criterion for diagnosing CTEPH on a V/Q scan is at least one massive defect after a minimum three-month effective anticoagulation therapy. The V/Q scan is 90$100 \%$ sensitive and $94-100 \%$ specific for diagnosing CTEPH. Possible errors for diagnosing CTEPH are caused by minor perfusion-like defects or nonsegmental perfusion abnormalities typical of otherwise caused PAH and pulmonary veno-occlusive disease. ${ }^{11}$ In addition, the classical segmental perfusion defects may disappear during the CTEPH terminal stage..$^{12}$ Perfusion scintigraphy appears nonsegmented in cases of large central thrombotic masses in Eisenmenger syndrome or thrombus within aneurysm of pulmonary trunk or pulmonary artery branches in idiopathic $\mathrm{PAH}^{13}$

Laboratory tests of blood, and biochemical and immunological tests are an integral part of etiological treatment of patients suspected of $\mathrm{PH}$ and other organ failures. Other routine analyses are thyroid hormone values and transaminase values, particularly after introduction of endothelin receptor antagonist therapy (ERA). Serological tests are compulsory in order to 
diagnose potential connective tissue disease (CTD), hepatitis and human immunodeficiency virus (HIV) hidden behind $\mathrm{PH}$. Up to $40 \%$ of patients suffering from idiopathic PAH have high antinuclear antibodies but in low titers $(1: 80){ }^{14}$

In most cases, TTE is an initial diagnostic method when there is a suspicion of $\mathrm{PH}$, whereas right heart catheterization (RHC) is a necessary invasive diagnostic procedure for the definite diagnosis and evaluation of pulmonary vascular reactivity. ${ }^{4}$ The left heart catheterization is simultaneously performed with patients in risk of coronary heart disease or left heart insufficiency with preserved left ventricular systolic function (HFpEF). It is recommended to perform RHC at specialized clinics as the procedure itself is technically demanding and might cause serious complications. Basic parameters crucial for monitoring with RHC are as follows: mPAP (mean pulmonary arterial pressure), PCWP (pulmonary capillary wedge pressure) and PVR (pulmonary vascular resistance). If it is not possible to measure PCWP, we determine left ventricular end-diastolic pressure in left ventricle (LVEDP). Vasoreactivity tests are recommended in all patients with idiopathic PAH, hereditary PAH and PAH accompanied by usage of weight-loss medications in order to determine patients who might be introduced with calcium channel blockers (CCB). Positive vasoreactivity tests are defined as a decrease of mPAP $\geq 10 \mathrm{mmHg}$ and absolute values of mPAP $\leq 40 \mathrm{mmHg}$ with an increased or unaltered stroke heart volume. In order to perform a vasoreactivity test, it is advised to use nitrogen monoxide (NO) or intravenous epoprostenol, whereas we may use adenosine or inhaled iloprost as the alternative. ${ }^{14-16}$ CCB therapy is absolutely contraindicated if the vasoreactivity test is negative.

\section{Therapy}

PAH therapy is a complex strategy which might be divided into three basic steps as follows: the initial approach and application of general measures, introduction of CCB therapy (only patients with positive vasoreactivity test) and/or specific PAH therapies, and finally, the third step which entails monitoring of the initial therapy response, introduction of combined PAH therapy, patient care during the terminal disease stage, and determining indications for lung transplantation.

General measures and supportive therapy. The recommendation is a regular physical activity which does not provoke symptoms and mandatory avoidance of severe physical exhaustion. It has been proven that the functional capacity and life quality of PAH patients who practise controlled physical activity are better that in those patients who are physically inactive. ${ }^{15-17} \mathrm{PAH}$ patients are advised to have influenza and pneumococcal pneumonia vaccines as these cause $7 \%$ of total deaths with this group of patients. ${ }^{14,15}$

PAH supporting therapy entails the oral anticoagulant therapy, oxygen therapy, right heart insufficiency therapy, and correction of anemia syndrome. The oral anticoagulant therapy is indicated only in patients with idiopathic and hereditary PAH and PAH due to weight-loss medication abuse. ${ }^{16-18}$ It is well-known that PAH patients also suffer from coagulation disorder and physiological fibrinolysis so it is crucial to takeinto account risks of venous thromboembolism (heart weakness and immobilization) and hemorrhage before the introduction of oral anticoagulant therapy. Particular caution should be paid in patients suffering from Eisenmenger syndrome..$^{18-20}$ The oxygen therapy is indicated in all PAH patients with $\mathrm{pO} 2<60 \mathrm{mmHg}(8 \mathrm{kPA})$ as hypoxia is one of major causes of vasoconstriction and this therapy decreases PVR. The usage of diuretics is indicated in all PAH patients with signs of right heart weakness or water retention. Digoxin improves stroke volume only in cases of acute aggravation in patients suffering from idiopathic PAH but its efficiency has not been proven for chronic usage. ${ }^{21}$ Digoxin is administered to $\mathrm{PAH}$ patients with acute aggravation primarily in order to slow down ventricular response in cases of atrial cardiac rhythm disturbance. The usage of ACE inhibitors, sartans, beta blockers and ivabradine is not recommended except in cases when these are an irreplaceable comorbidity therapy (eg. arterial hypertension, coronary heart disease). Sideropenic anemia is registered with around $43 \%$ idiopathic PHA patients and 56\% Eisenmenger syndrome patients, in which cases it also predicts mortality so it is crucial to monitor the iron values and substitute the treatment if necessary. ${ }^{22-24}$ Eisenmenger patients are a particularly sensitive group because frequent and unfounded venipuncture cause these patients severe anemia syndrome, which further increases mortality rates. ${ }^{25}$ Therefore, prior to venipuncture, these patients should be examined by cardiologists specialized in PAH treatments. ${ }^{26}$

Specific therapy. The specific PAH patient therapy covers the following classes of medications: $\mathrm{CCB}$, endothelin receptor antagonists (ERA), phosphodiesterase type 5 inhibitors (PDE-5i) and guanylate cyclase stimulators (sGC), prostacyclin analogues and prostacyclin receptor antagonists. It is well-known that only few patients suffering from idiopathic PAH have positive vasoreactivity test, which is the only indication for $\mathrm{CCB}$ therapy. The CCBs used in PAH therapy are nifedipine, diltiazem and amlodipine. In addition, their regular dosage is $120-240 m g$ for nifedipine, 240-720mg for diltiazem and up to 20mg for amlodipine, depending 
on tolerance.4 Endothelin receptor antagonists (ERA) are widely used in $\mathrm{PH}$ therapy due to the fact that these patients also suffer from activation in endothelial cells in both plasma and pulmonary tissue although it is still not quite clear if the increase of plasma endothelin-1 level causes $\mathrm{PH}$ or results from it. ${ }^{27,28}$ ERA medications used in current PH therapy for diagnostics and treatment of PAH are ambrisentan, bosentan and macitentan. ${ }^{4}$

The fact that pulmonary vascular network contains certain amounts of phosphodiesterase type 5 is the basis for the application of PDE-5i in PH therapy due to both consequential vasodilatation and antiproliferative effect. All three PDE-5 inhibitors approved for treatment of erectile dysfunction (sildenafil, tadalafil, vardenafil) cause massive vasodilatation of pulmonary vascular network. ${ }^{29,30}$ Unlike PDE-5i, sGC (riociguat) increases cyclic guanosine monophosphate production (cGMP) and causes vasodilatation and antiproliferative effect. ${ }^{31}$ The efficiency of riociguat application in $\mathrm{PH}$ therapy has been proven positive when combined with ERA or prostanoid therapy in $2.5 \mathrm{mg}$ three times per day dosage in sense that it improves functional capacities of patients as well as hemodynamic parameters. ${ }^{32}$ Combination of riociguat and $\mathrm{PDE}-5 \mathrm{i}$ therapies is contraindicated due to strong hypotension.

The usage of prostacyclin analogues and prostacyclin receptor antagonists in $\mathrm{PH}$ therapy is based on the role and relevance of prostacyclin in $\mathrm{PH}$ pathogenesis. Prostacyclin, produced primarily by endothelial cells, is a potent vasodilator and endogenous inhibitor of platelet aggregation and it also has proven cytoprotective and antiproliferative properties. Clinical use of prostacyclin in $\mathrm{PH}$ therapy is enabled due to synthesis of stable prostacyclin analogues which have different pharmacokinetic properties but still similar pharmacodynamic effects. Medications from this class approved for PH treatment are beraprost, epoprostenol, iloprost and treprostinil and their most common indications are for treatment of WHO FC III and IV. Selexipag, a selective IP prostacyclin receptor agonist is available for oral usage as well as monotherapy or supplement to mono and dual therapy for $\mathrm{PH}$ patients in WHO FC II and III with ERA and/or PDE-5i in which cases it decreases morbidity and mortality per $40 \% .^{33}$

Combined therapy and transplantation. The combined $\mathrm{PH}$ therapy implies simultaneous usage of two or more $\mathrm{PH}$ medicaments from different classes in which process it is possible to initiate therapy with one medicament and then introduce medicaments from another class or initially start therapy with two medicaments from different classes. The initial combined therapy is justified by the fact that $\mathrm{PH}$ patients share high mortality rates with many other malignant diseases. ${ }^{4}$

Balloon atrial septostomy (BAS) is a palliative method of $\mathrm{PH}$ treatment which results in the interatrial rightleft shunt targeting at the right heart decompression, improvement of left heart function, and enhancement of stroke volume. Some published studies demonstrate benefits of this treatment with patients in WHO FC IV who show signs of right heart weakness and who are refractory to optimal medication therapy and suffer from sever syncope. ${ }^{34-36}$ In addition, the treatment is optional for patients awaiting lung transplantation who show no significant clinical improvement after the maximum combined medicament therapy.

Transplantation is a final therapy for $\mathrm{PH}$ patients who remain in WHO FC III or IV despite the maximum combined and supportive medicament therapy. Delayed transplantation combined with long waiting lists due to the pragmatic lack of organ donors increases mortality rates and causes clinical aggravation at the moment of transplantation. Recent data indicate additional 5-year life span with 52-75\% of $\mathrm{PH}$ patients after transplantation and additional 10-year life span with around 45-66\% of these patients. ${ }^{37} \mathrm{PH}$ patients are administered heart-lung transplantations as well as double-lung transplantations even though there is no information on the limits of irreversible stress of right ventricular systolic function and/or left ventricular diastolic function..$^{38}$ According to the International Registry for Heart and Lung Transplantation, most patients worldwide have doublelungs transplants. ${ }^{39}$ Patients suffering from Eisenmenger syndrome and simple shunts have lung transplantations and surgical corrections of congenital heart defects or heart and lung transplantations..$^{\circ}$

\section{References}

1. Galie N, Humbert M, Vachiery JL, Gibbs S, Lang I, Torbicki A, et al. 2015 ESC/ERS Guidelines for the Diagnosis and Treatment of Pulmonary Hypertension. Rev Esp Cardiol (Engl Ed). 2016;69(2):177.

https://doi.org/10.1016/j.recesp.2016.01.002

2. Benza RL, Miller DP, Gomberg-Maitland M, Frantz RP, Foreman AJ, Coffey CS, et al. Predicting survival in pulmonary arterial hypertension: insights from the Registry to Evaluate Early and Long-Term Pulmonary Arterial Hypertension Disease Management (REVEAL). Circulation. 2010;122(2):164-72.

https://doi.org/10.1161/CIRCULATIONAHA.109.898122 PMid:20585012

3. Lang IM, Plank C, Sadushi-Kolici R, Jakowitsch J, Klepetko W, Maurer G. Imaging in pulmonary hypertension. JACC Cardiovasc Imaging. 2010;3(12):1287-95. https://doi.org/10.1016/j.jcmg.2010.09.013 PMid:21163459 
4. Galie N, Humbert M, Vachiery JL, Gibbs S, Lang I, Torbicki A, et al. 2015 ESC/ERS Guidelines for the diagnosis and treatment of pulmonary hypertension: The Joint Task Force for the Diagnosis and Treatment of Pulmonary Hypertension of the European Society of Cardiology (ESC)and the European Respiratory Society (ERS): Endorsed by: Association for European Paediatric and Congenital Cardiology (AEPC), International Society for Heart and Lung Transplantation (ISHLT). Eur Heart J. 2016;37(1):67-119.

https://doi.org/10.1093/eurheartj/ehv317

PMid:26320113

5. Rudski LG, Lai WW, Afilalo J, Hua L, Handschumacher MD, Chandrasekaran $\mathrm{K}$, et al. Guidelines for the echocardiographic assessment of the right heart in adults: a report from the American Society of Echocardiography endorsed by the European Association of Echocardiography, a registered branch of the European Society of Cardiology, and the Canadian Society of Echocardiography. J Am Soc Echocardiogr. 2010;23(7):685-713; quiz 86-8. https://doi.org/10.1016/j.echo.2010.05.010 PMid:20620859

6. Montani D, Achouh L, Sitbon O, Simonneau G, Humbert M. Pulmonary venoocclusive disease and failure of specific therapy. Chest. 2009;136(4):1181; author reply -2.

7. Dufour B, Maitre S, Humbert M, Capron F, Simonneau G, Musset D. High-resolution CT of the chest in four patients with pulmonary capillary hemangiomatosis or pulmonary venoocclusive disease. AJR Am J Roentgenol. 1998;171(5):1321-4.

https://doi.org/10.2214/ajr.171.5.9798872 PMid:9798872

8. Tunariu N, Gibbs SJ, Win Z, Gin-Sing W, Graham A, Gishen P, et al. Ventilation-perfusion scintigraphy is more sensitive than multidetector CTPA in detecting chronic thromboembolic pulmonary disease as a treatable cause of pulmonary hypertension. J Nucl Med. 2007;48(5):6804.

https://doi.org/10.2967/jnumed.106.039438

PMid:17475953

9. Fedullo PF, Auger WR, Kerr KM, Rubin LJ. Chronic thromboembolic pulmonary hypertension. N Engl J Med. 2001;345(20):1465-72.

https://doi.org/10.1056/NEJMra010902

PMid:11794196

10. Reichelt A, Hoeper MM, Galanski M, Keberle M. Chronic thromboembolic pulmonary hypertension: evaluation with 64-detector row CT versus digital substraction angiography. Eur J Radiol. 2009;71(1):49-54.

https://doi.org/10.1016/j.ejrad.2008.03.016

PMid:18462902

11. Bailey CL, Channick RN, Auger WR, Fedullo PF, Kerr KM, Yung GL, et al. "High probability" perfusion lung scans in pulmonary venoocclusive disease. Am J Respir Crit Care Med. 2000;162(5):1974-8.

https://doi.org/10.1164/ajrccm.162.5.2003045

\section{PMid:11069842}

12. Skoro-Sajer N, Becherer A, Klepetko W, Kneussl MP, Maurer G, Lang IM. Longitudinal analysis of perfusion lung scintigrams of patients with unoperated chronic thromboembolic pulmonary hypertension. Thromb Haemost. 2004;92(1):201-7. https://doi.org/10.116o/tho3-11-0727

13. Moser KM, Fedullo PF, Finkbeiner WE, Golden J. Do patients with primary pulmonary hypertension develop extensive central thrombi? Circulation. 1995;91(3):7415 . https://doi.org/10.1161/o1.CIR.91.3.741 PMid:7828302

14. "2015 ESC/ERS Guidelines for the diagnosis and treatment of pulmonary hypertension. The Joint Task Force for the Diagnosis and Treatment of Pulmonary Hypertension of the European Society of Cardiology (ESC) and the European Respiratory Society (ERS).” Nazzareno Galie, Marc Humbert, Jean-Luc Vachiery, Simon Gibbs, Irene Lang, Adam Torbicki, Gerald Simonneau, Andrew Peacock, Anton Vonk Noordegraaf, Maurice Beghetti, Ardeschir Ghofrani, Miguel Angel Gomez Sanchez, Georg Hansmann, Walter Klepetko, Patrizio Lancellotti, Marco Matucci, Theresa McDonagh, Luc A. Pierard, Pedro T. Trindade, Maurizio Zompatori and Marius Hoeper. Eur Respir J 2015; 46: 903-975. Eur Respir J. 2015;46(6):1855-6. https://doi.org/10.1183/13993003.51032-2015 PMid:26621899

15. Mereles D, Ehlken N, Kreuscher S, Ghofrani S, Hoeper MM, Halank M, et al. Exercise and respiratory training improve exercise capacity and quality of life in patients with severe chronic pulmonary hypertension. Circulation. 2006;114(14):1482-9.

https://doi.org/10.1161/CIRCULATIONAHA.106.618397 PMid:16982941

16. Grunig E, Ehlken N, Ghofrani A, Staehler G, Meyer FJ, Juenger J, et al. Effect of exercise and respiratory training on clinical progression and survival in patients with severe chronic pulmonary hypertension. Respiration. 2011;81(5):394-401.

https://doi.org/10.1159/ooo322475 PMid:21311162

17. Grunig E, Maier F, Ehlken N, Fischer C, Lichtblau M, Blank N, et al. Exercise training in pulmonary arterial hypertension associated with connective tissue diseases. Arthritis Res Ther. 2012;14(3):R148.

https://doi.org/10.1186/ar3883 PMid:22709477 PMCid:PMC3446533

18. Hoeper MM, Sosada M, Fabel H. Plasma coagulation profiles in patients with severe primary pulmonary hypertension. Eur Respir J. 1998;12(6):1446-9. https://doi.org/10.1183/09031936.98.12061446 PMid:9877507

19. Huber K, Beckmann R, Frank H, Kneussl M, Mlczoch J, Binder BR. Fibrinogen, t-PA, and PAI-1 plasma levels in 
patients with pulmonary hypertension. Am J Respir Crit Care Med. 1994;150(4):929-33.

https://doi.org/10.1164/ajrccm.150.4.7921465

PMid:7921465

20. Herve P, Humbert M, Sitbon O, Parent F, Nunes H, Legal C, et al. Pathobiology of pulmonary hypertension. The role of platelets and thrombosis. Clin Chest Med. 2001;22(3):4518.

https://doi.org/10.1016/So272-5231(05)70283-5

21. Rich S, Seidlitz M, Dodin E, Osimani D, Judd D, Genthner $\mathrm{D}$, et al. The short-term effects of digoxin in patients with right ventricular dysfunction from pulmonary hypertension. Chest. 1998;114(3):787-92.

https://doi.org/10.1378/chest.114.3.787 PMid:9743167

22. Ruiter G, Lankhorst S, Boonstra A, Postmus PE, Zweegman $\mathrm{S}$, Westerhof $\mathrm{N}$, et al. Iron deficiency is common in idiopathic pulmonary arterial hypertension. Eur Respir J. 2011;37(6):1386-91.

https://doi.org/10.1183/09031936.00100510 PMid:20884742

23. Ruiter G, Lanser IJ, de Man FS, van der Laarse WJ, Wharton J, Wilkins MR, et al. Iron deficiency in systemic sclerosis patients with and without pulmonary hypertension. Rheumatology (Oxford). 2014;53(2):285-92.

https://doi.org/10.1093/rheumatology/ket331 PMid:24155365

24. Broberg CS, Bax BE, Okonko DO, Rampling MW, Bayne $\mathrm{S}$, Harries $\mathrm{C}$, et al. Blood viscosity and its relationship to iron deficiency, symptoms, and exercise capacity in adults with cyanotic congenital heart disease. J Am Coll Cardiol. 2006;48(2):356-65.

https://doi.org/10.1016/j.jacc.2006.03.040

PMid:16843187

25. Van De Bruaene A, Delcroix M, Pasquet A, De Backer J, De Pauw M, Naeije R, et al. Iron deficiency is associated with adverse outcome in Eisenmenger patients. Eur Heart J. 2011;32(22):2790-9.

https://doi.org/10.1093/eurheartj/ehr130 PMid:21606083

26. Warnes CA, Williams RG, Bashore TM, Child JS, Connolly HM, Dearani JA, et al. ACC/AHA 2008 guidelines for the management of adults with congenital heart disease: a report of the American College of Cardiology/American Heart Association Task Force on Practice Guidelines (Writing Committee to Develop Guidelines on the Management of Adults With Congenital Heart Disease). Developed in Collaboration With the American Society of Echocardiography, Heart Rhythm Society, International Society for Adult Congenital Heart Disease, Society for Cardiovascular Angiography and Interventions, and Society of Thoracic Surgeons. J Am Coll Cardiol. 2008;52(23):e143-263.

https://doi.org/10.1016/j.jacc.2008.10.001 PMid:19038677
27. Giaid A, Yanagisawa M, Langleben D, Michel RP, Levy R, Shennib H, et al. Expression of endothelin-1 in the lungs of patients with pulmonary hypertension. N Engl J Med. 1993;328(24):1732-9.

https://doi.org/10.1056/NEJM199306173282402 PMid:8497283

28. Stewart DJ, Levy RD, Cernacek P, Langleben D. Increased plasma endothelin-1 in pulmonary hypertension: marker or mediator of disease? Ann Intern Med. 1991;114(6):4649 .

https://doi.org/10.7326/ooo3-4819-114-6-464 PMid:1994793

29. Ghofrani HA, Voswinckel R, Reichenberger F, Olschewski H, Haredza P, Karadas B, et al. Differences in hemodynamic and oxygenation responses to three different phosphodiesterase- 5 inhibitors in patients with pulmonary arterial hypertension: a randomized prospective study. J Am Coll Cardiol. 2004;44(7):1488-96. https://doi.org/10.1016/So735-1097(04)01362-2 https://doi.org/10.1016/j.jacc.2004.06.060 PMid:15464333

30. Tantini B, Manes A, Fiumana E, Pignatti C, Guarnieri C, Zannoli R, et al. Antiproliferative effect of sildenafil on human pulmonary artery smooth muscle cells. Basic Res Cardiol. 2005;100(2):131-8.

https://doi.org/10.1007/so0395-004-0504-5 PMid:15739122

31. Giaid A, Saleh D. Reduced expression of endothelial nitric oxide synthase in the lungs of patients with pulmonary hypertension. N Engl J Med. 1995;333(4):214-21. https://doi.org/10.1056/NEJM199507273330403 PMid:7540722

32. Ghofrani HA, Galie N, Grimminger F, Grunig E, Humbert $\mathrm{M}$, Jing ZC, et al. Riociguat for the treatment of pulmonary arterial hypertension. N Engl J Med. 2013;369(4):330-40. https://doi.org/10.1056/NEJMoa1209657 https://doi.org/10.1056/NEJMoa1209655 PMid:23883378

33. Sitbon O, Channick R, Chin KM, Frey A, Gaine S, Galie N, et al. Selexipag for the Treatment of Pulmonary Arterial Hypertension. N Engl J Med. 2015;373(26):2522-33. https://doi.org/10.1056/NEJMoa1503184 PMid:26699168

34. Sandoval J, Gaspar J, Pulido T, Bautista E, MartinezGuerra ML, Zeballos M, et al. Graded balloon dilation atrial septostomy in severe primary pulmonary hypertension. A therapeutic alternative for patients nonresponsive to vasodilator treatment. J Am Coll Cardiol. 1998;32(2):297304. https://doi.org/10.1016/So735-1097(98)00238-1

35. Kurzyna M, Dabrowski M, Bielecki D, Fijalkowska A, Pruszczyk P, Opolski G, et al. Atrial septostomy in treatment of end-stage right heart failure in patients with pulmonary hypertension. Chest. 2007;131(4):977-83. https://doi.org/10.1378/chest.o6-1227 
PMid:17426198

36. Keogh AM, Mayer E, Benza RL, Corris P, Dartevelle PG, Frost AE, et al. Interventional and surgical modalities of treatment in pulmonary hypertension. J Am Coll Cardiol. 2009;54(1 Suppl):S67-77.

https://doi.org/10.1016/j.jacc.2009.04.016 PMid:19555860

37. Toyoda Y, Thacker J, Santos R, Nguyen D, Bhama J, Bermudez C, et al. Long-term outcome of lung and heartlung transplantation for idiopathic pulmonary arterial hypertension. Ann Thorac Surg. 2008;86(4):1116-22. https://doi.org/10.1016/j.athoracsur.2008.05.049 PMid:18805144

38. Fadel E, Mercier O, Mussot S, Leroy-Ladurie F, Cerrina J, Chapelier A, et al. Long-term outcome of double-lung and heart-lung transplantation for pulmonary hypertension: a comparative retrospective study of 219 patients. Eur J
Cardiothorac Surg. 2010;38(3):277-84. https://doi.org/10.1016/j.ejcts.2010.02.039 PMid:20371187

39. Christie JD, Edwards LB, Kucheryavaya AY, Benden C, Dipchand AI, Dobbels F, et al. The Registry of the International Society for Heart and Lung Transplantation: 29th adult lung and heart-lung transplant report-2012. J Heart Lung Transplant. 2012;31(10):1073-86. https://doi.org/10.1016/j.healun.2012.08.004 PMid:22975097

40. Trulock EP, Edwards LB, Taylor DO, Boucek MM, Keck BM, Hertz MI, et al. Registry of the International Society for Heart and Lung Transplantation: twentythird official adult lung and heart-lung transplantation report--2006. J Heart Lung Transplant. 2006;25(8):88092. https://doi.org/10.1016/j.healun.2006.06.001 PMid:16890108

\section{Dijagnostika i terapija plućne hipertenzije}

\section{SAŽETAK}

Plućna hipertenzija $(\mathrm{PH})$ predstavlja hemodinamski poremećaj definisan kao porast srednjeg pritiska u plućnoj arteriji od $25 \mathrm{mmHg}$ ili više u miru. Razlikuje se pet grupa pacijenata: grupa 1- plućna arterijska hipertenzija (PAH), grupa 2- PH kao posljedica bolesti lijevog srca, grupa 3- PH kao posljedica bolesti pluća, grupa 4 - hronična tromboembolijska PH i grupa 5- PH drugih uzroka. PAH je brzo progresivna i fatalna bolest sa incidencom od oko 3 slučaja na milion stanovnika, dok je incidenca $\mathrm{PH}$ kao posljedice bolesti lijevog srca prisutna kod čak 60-70\% ovih pacijenata. Plućni kapilarni pritisak, mjeren invazivno u miru, omogućava razlikovanje prekapilarne $(\leq 15 \mathrm{mmHg})$ i postkapilarne $(>15 \mathrm{mmHg}) \mathrm{PH}$. Rani klinički simptomi i znaci su veoma diskretni i nespecifični u obliku dispneje pri naporu, slabosti, presinkope i progresivnog smanjenja tolerancije fizičkog napora te najveći broj pacijenata ima teži stadijum bolesti sa funkcionalnom klasom Svjetske zdravstvene organizacije III ili IV pri prvom pregledu. Dijagnostički proces PH ima za cilj evaluaciju dvije osnovne anatomske komponente: plućna vaskulatura i desna komora srca sa ciljem postavljanja dijagnoze i identifikovanja grupe PH. Terapija pacijenata sa PAH se sastoji iz tri osnovna koraka: opšte mjere i suportivna terapija; inicijalna terapija blokatorima kalcijumskih kanala kod vazoreaktivnih odnosno specifičnih lijekova za PAH kod ne-vazoreaktivnih pacijenata bilo pojedinačno ili u kombinacijama te transplantacija pluća. Sve pacijente sa PAH je potrebno uputiti u ekspertske centre za dijagnostiku i liječenje PH.

Ključne riječi: Plućna hipertenzija, desna komora, plućni kapilarni pritisak 